\title{
CEMARAN ANGKA LEMPENG TOTAL (ALT) DAN ANGKA KAPANG KHAMIR (AKK) PADA BOLU KUKUS DENGAN LAMA PENYIMPANAN 3 HARI
}

\author{
STANDARD PLATE COUNT, YEAST AND MOLD PLATE \\ COUNT OF TRADITIONAL STEAMED CAKE AFTER 3 DAYS \\ OF STORAGE
}

\author{
Dewa Ayu Sri Noviawati, Ni Wayan Desi Bintari, Made Sudiari. \\ Program Studi Analis Kesehatan (DIII) Sekolah Tinggi Ilmu Kesehatan Wira \\ Medika Bali . \\ Jalan Kecak No. 9A, Gatot Subroto Timur Denpasar, Bali 80239, \\ Email: Srinoviawati85@gmail.com
}

\begin{abstract}
ABSTRAK
Pendahuluan: Bolu kukus merupakan jajanan pasar yang digemari oleh semua kalangan masyarakat. Jajanan ini memiliki daya simpan yang singkat. Penyimpanan bolu kukus lebih dari 3 hari dapat meningkatkan faktor resiko pertumbuhan jamur dan bakteri kontaminan. Tujuan penelitian ini adalah untuk mengetahui cemaran Angka Lempeng Total (ALT) dan Angka Kapang Khamir (AKK) pada bolu kukus yang di produksi oleh prodeusen di Desa Bebalang Bangli dengan lama penyimpanan 3 hari pada suhu ruangan $\left(27^{\circ} \mathrm{C}\right)$ dan mengidentifikasi jamur apa saja yang mengkontaminasi bolu kukus. Metode: Penelitian yang digunakan adalah eksperimental, sampel yang digunakan adalah bolu kukus yang dibuat oleh produsen yang kurang dari 18 jam. Jumlah sampel yang digunakan adalah 15 buah bolu kukus dari 3 produsen rumah tangga. Hasil: Angka Lempeng Total (ALT) pada produsen A sebanyak $897 \times 10^{4} \mathrm{CFU} / \mathrm{mL}$, Produsen B sebanyak $86 \times 10^{4}$ $\mathrm{CFU} / \mathrm{mL}$, Produsen $\mathrm{C}$ sebanyak $167 \times 10^{4} \mathrm{CFU} / \mathrm{mL}$. Hasil penelitian Angka Kapang Khamir (AKK) didapatkan hasil yang melebihi batas standar SNI 7388-2009, menyatakan standar Angka Kapang Khamir (AKK) pada roti yaitu batas maksimum $1 \times 10^{4} \mathrm{koloni} / \mathrm{g}$. Hasil Angka Kapang Khamir (AKK) Produsen A sebanyak $1,85 \times 10^{4} \mathrm{CFU} / \mathrm{mL}$, Produsen B sebanyak $8,4 \times 10^{4} \mathrm{CFU} / \mathrm{mL}$, Produsen $\mathrm{C}$ sebanyak $12,5 \times 10^{4} \mathrm{CFU} / \mathrm{mL}$. Hasil pengamatan jamur kontaminan didapatkan 3 spesies jamur yaitu Aspergillus flavus, Aspergillus fumigatus dan Rhizopus stolonifer. Diskusi: Hasil penelitian yang telah dilakukan didapatkan hasil yang melebihi batas standar SNI 7388-2009 yang sudah ditetapkan yaitu ALT dan AKK batas maksimum $1 \times 10^{4} \mathrm{koloni} / \mathrm{g}$.
\end{abstract}

Kata kunci : Angka Lempeng Total (ALT) Angka Kapang Khamir (AKK), bolu kukus, Aspergillus flavus, Aspergillus fumigatus dan Rhizopus stolonifer.

Introduction: Steamed cake or "bolu kukus" is one of the most favorite cake in traditional market. Steamed cake has a short shelf life, in more than 3 days of storage it may increase risk factors of bacteria and mold contamination. The aim of this research is to know bacterial and mold contamination of traditional steam cake using standard plate count and yeast and mold plate count after 3 days of storage 
$\left(27^{\circ} \mathrm{C}\right)$ and also to identify type of mold in sample. Method: Type of this study is experimental study, using 15 steamed cake as a sample. Sample taken from 3 traditional steamed cake producer in Bebalang Village, Bangli and stored in room temperature $\left(27^{\circ} \mathrm{C}\right)$. Result: Meanwhile in sample the total bacteria using standard plate count are $897 \times 10^{4}$ colony/g (A producer), $86 \times 10^{4}$ colony/g (B producer) and $167 \times 10^{4}$ colony/g (producer C). Yeast and mold plate count also show that contamination are more than SNI $7388-2009\left(1 \times 10^{4}\right.$ colony/g). The result show that yeast and mold contamination are $1.85 \times 10^{4}$ colony $/ \mathrm{g}$ (A Producer), $8.4 \times 10^{4}$ colony/g (B producer) and $12.5 \times 10^{4}$ colony/g (C Producer). Identification result show that mold contaminant in traditional steamed cake are Aspergillus flavus, Aspergillus fumigatus and Rhizopus stolonifer. Discussion: The result of this study show that total bacterial and fungi of steamed cake after 3 days of storage are more than standard using Standar National Indonesia 7388-2009 (SNI 7388-2009). The maximum contaminant level of bacteria using SNI 7388-2009 is $1 \times 10^{4}$ colony/g.

Key words : Standard Plate Count, Yeast and Mold Plate Count, Aspergillus flavus, Aspergillus fumigatus, Rhizopus stolonifer, Traditional Steamed Cake.

Alamat Korespodensi : Lc Subak Aya Bangli, Kabupaten Bangli

Email : Srinoviawati85@gmail.com

PENDAHULUAN

Bolu kukus merupakan salah satu jajanan pasar yang digemari dan dikenal oleh masyarakat di semua kalangan. Bolu kukus setelah proses produksi hanya mampu bertahan 2-3 hari saja. Apabila disimpan lebih dari 3 hari bolu kukus sangat berpotensi berjamur dan berair (Handayani, 2015). Hal tersebut menurut Kusuma (2008), disebabkan oleh kandungan bahan utama bolu kukus. Tepung terigu yang menjadi bahan dasar dalam pembuatan bolu kukus mengandung pati dalam jumlah yang relatif tinggi. Pati ini dapat dihidrolisis menjadi gula sederhana oleh mikroorganisme khususnya jamur, karena gula sederhana merupakan sumber nutrisi utama bagi mikroorganisme tersebut.

Menurut SNI 7388-2009, menyatakan standar angka kapang khamir (AKK) dan angka lempeng total (ALT) pada roti yaitu kapang dan khamir batas maksimum $1 \times 10^{4} \mathrm{koloni} / \mathrm{g}$ sedangkan ALT $\left(30^{\circ} \mathrm{C}, 72 \mathrm{jam}\right)$ batas maksimum $1 \times 10^{4} \mathrm{koloni} / \mathrm{g}$. Bakteri yang berpotensi tinggi untuk mengkontaminasi roti seperti mikroorganisme Staphylococcus aureus dan berbagai Enterobacteriaceae karena bahan dan metode produksinya. Selain bakteri produk roti juga dapat dikontaminasi oleh jamur antara lain oleh Rhizopus sp., Penicillium sp., Mucor sp., Aspergillus sp. dan jenis jamur lainnya (Koswara 2009).

Masyarakat Hindu di Bali umumnya pada saat upacara adat dan agama lebih menggemari menggunakan bolu kukus, karena lebih menarik dari segi warna dan tampilannya. Akan tetapi masyarakat kurang memperhatikan lama penyimpanan bolu kukus yang layak dikonsumsi. Berdasarkan hasil survei di Desa Bebalang Bangli diketahui bahwa masyarakat sangat sering menggunakan bolu kukus sebagai sarana upacara. Namun masyarakat kurang memperhatikan kondisi dan lama penyimpanan bolu kukus. Apabila bolu kukus disimpan dalam waktu yang lama maka berpotensi adanya kontaminasi dari jamur dan bakteri. Masyarakat juga 
kurang memahami adanya potensi pertumbuhan jamur dan bakteri pada produk bolu kukus yang berbahaya bagi kesehatan.

\section{BAHAN DAN METODE}

Jenis penelitian ini adalah eksperimetal. Populasi dalam penelitian ini adalah seluruh produsen yang memproduksi bolu kukus di Desa Bebalang Bangli Kabupaten Bangli yang berjumlah 3 produsen rumah tangga. Sampel yang digunakan adalah bolu kukus dengan lama penyimpanan kurang dari 18 jam. Jumlah sampel yang digunakan pada penelitian sebanyak 5 buah pada setiap produsen dengan total sampel yang digunakan sebanyak 15 sampel.

Penanaman sampel untuk analisa ALT dan AKK menggunakan metode dilusi/ pengenceran. Bolu kukus yang telah diberikan perlakukan penyimpanan selama 3 hari ditimbang sebanyak 10 gram, dimasukkan kedalam media Pepton 90mL, kemudian dihomogenkan dengan vortex selama 30 detik. Faktor pengenceran kemudian dipipet menggunakan mikropipet sebanyak $1 \mathrm{~mL}$ dan diinokulasikan ke media pepton $9 \mathrm{~mL}$, selanjutnya dihomogenkan. Prosedur yang sama diulangi hingga faktor pengenceran $10^{-6}$.

Pengenceran $10^{-6}$ dan $10^{-5}$ ditanam pada media PCA dan pada pengenceran $10^{-4}$ dan $10^{-3}$ di tanam pada media SDA secara pour plate. Jamur yang tumbuh pada media SDA dilakukan pengamatan mikroskopis dengan melakukan pewarnaan lactofenol blue dan diidentifikasi.

\section{HASIL PENELITIAN}

Hasil pengamatan dari Angka Lempeng Total (ALT) dari sampel bolu kukus yang disimpan selama 3 hari pada suhu ruangan $\left(27^{\circ} \mathrm{C}\right)$ didapatkan hasil pada produsen 1 yaitu $897 \times 10^{4} \mathrm{CFU} / \mathrm{mL}$, produsen 2 yaitu $86 \times 10^{4} \mathrm{CFU} / \mathrm{mL}$ dan produsen 3 yaitu $167 \times 10^{4} \mathrm{CFU} / \mathrm{mL}$. Hasil tersebut menunjukkan Angka Lempeng Total (ALT) bolu kukus dari 3 produsen melebihi standar SNI 7388-2009 yang sudah ditetapkan yaitu ALT dengan batas maksimum $1 \times 10^{4} \mathrm{koloni} / \mathrm{g}$.

Tabel 1. Hasil Angka Lempeng Total (ALT)

\begin{tabular}{cc}
\hline Sampel & ALT $($ CFU $/ \mathbf{m L})$ \\
\hline A (Produsen 1) & $897 \pm 458 \times 10^{4} \mathrm{CFU} / \mathrm{mL}$ \\
\hline B (Produsen 2) & $86 \pm 100 \times 10^{4} \mathrm{CFU} / \mathrm{mL}$ \\
\hline C (Produsen 3) & $167 \pm 203 \times 10^{4} \mathrm{CFU} / \mathrm{mL}$ \\
\hline
\end{tabular}

* Keterangan

Hasil Angka Lempeng Total (ALT) merupakan hasil rata-rata dari 5 kali pengulangan. Standar deviasi diperoleh rata-rata dari 5 kali pengulangan.

Hasil pengamatan dari Angka Kapang Khamir (AKK) dari sampel bolu kukus yang disimpan selama 3 hari pada suhu ruangan $\left(27^{\circ} \mathrm{C}\right)$ didapatkan hasil pada produsen 1 sebanyak $1,85 \times 10^{4} \mathrm{CFU} / \mathrm{mL}$, produsen 2 sebanyak $8,4 \times 10^{4} \mathrm{CFU} / \mathrm{mL}$ dan produsen 3 sebanyak $12,3 \times 10^{4} \mathrm{CFU} / \mathrm{mL}$. Hasil tersebut menjukkan Angka Kapang Khamir (AKK) bolu kukus dari 3 produsen melebihi standar SNI 73882009 yang sudah ditetapkan pada roti yaitu kapang dan khamir dengan batas maksimum $1 \times 10^{4} \mathrm{koloni} / \mathrm{g}$. 
Tabel 2. Hasil Angka Kapang Khamir (AKK)

\begin{tabular}{cc}
\hline Sampel & AKK $(\mathbf{C F U} / \mathrm{mL})$ \\
\hline A (Produsen 1) & $1,85 \pm 1,2 \times 10^{4} \mathrm{CFU} / \mathrm{mL}$ \\
\hline B (Produsen 2) & $8,4 \pm 8,3 \times 10^{4} \mathrm{CFU} / \mathrm{mL}$ \\
\hline C (Produsen 3) & $12,3 \pm 7,4 \times 10^{4} \mathrm{CFU} / \mathrm{mL}$
\end{tabular}

* Keterangan

Hasil Angka Kapang Khamir (AKK) merupakan hasil rata-rata dari 5 kali pengulangan. Standar deviasi diperoleh rata-rata dari 5 kali pengulangan.

Berdasarkan hasil pengamatan yang telah dilakukan didapatkan jenis jamur yang mengkontaminasi bolu kukus yang disimpan selama 3 hari yaitu jamur Aspergillus flavus didapatkan pada produsen 1 dan produsen 2, Aspergillus fumigatus didapatkan pada produsen 2 dan 3 dan Rhizopus stolonifer didapatkan pada produsen 1 dan produsen 3.

a. Aspergillus flavus

Koloni jamur Aspergillus flavus memiliki warna kuning kehijauan sampai hijau tua. Aspergillus flavus memilki konidiofor yang panjang dan halus, dan konidia berbentuk bulat, memilki hifa yang berseptum (jamak septa).
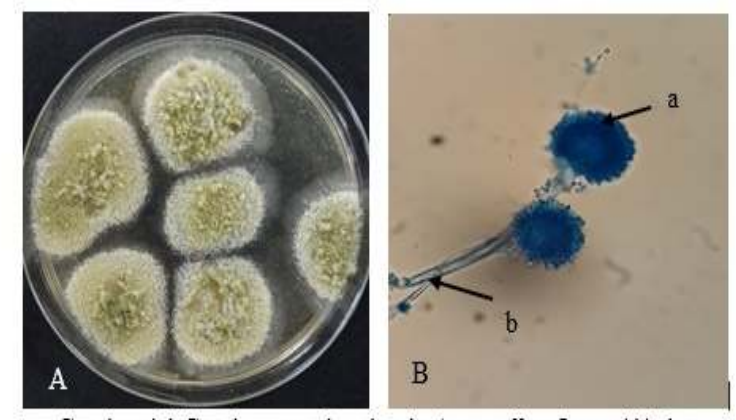

Gambar 4.1 Gambaran makroskopis Aspergillus flavus (A) dan mikroskopis (B) Aspergillus flavus pada media SDA. Bagian-bagian dari Aspergillus flavus : $a$. Konidia, b. Konidiofor.

b. Aspergillus fumigatus

Koloni jamur Aspergillus fumigatus memilki warna hijau kebiruansampai hijau tua dengan tepi putih. Mikroskopis Aspergillus fumigatus konidia berbentuk kolumer (memanjang), konidiofor berdinding kasar, memilki hifa yang berseptum (jamak septa). 


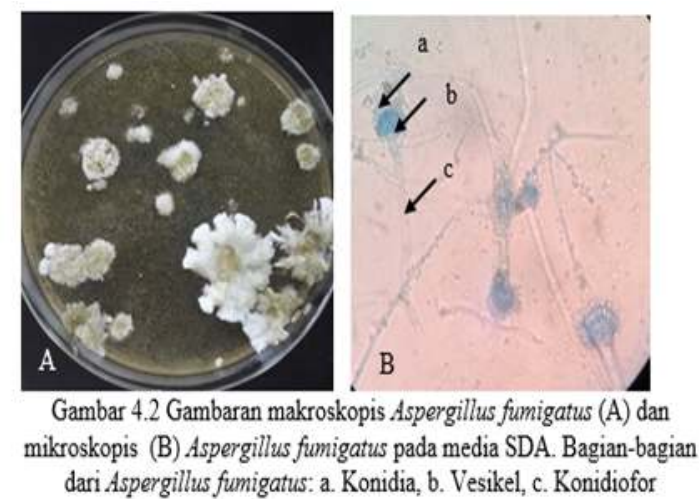

\section{c. Rhizopus stolonifer}

Koloni jamur Rhizopus stolonifer memiliki warna putih keabuan, terlihat seperti kapas, dan memilki hifa yang panjang. Pada pengamatan mikroskopis terdapat kolumela yang berbentuk bulat, sporangiofor yang panjang, dan memilki sporangiospora, memilki hifa yang tidak berseptum.
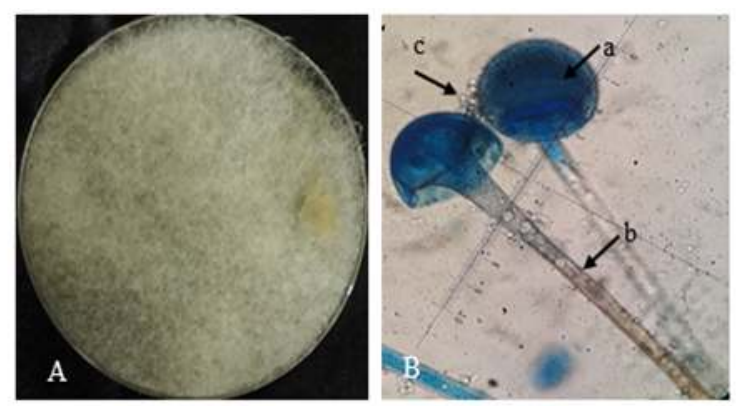

Gambar 4.2 Gambaran makroskopis Rhizopus stolonifer (A) dan mikroskopis (B) Rhizopus stolonifer pada media SDA. Bagianbagian dari Rhizopus stolonifer : a. Kolumela, b. Sporangiofor, c. Sporangispora

\section{PEMBAHASAN}

Hasil dari penelitian ini, didapatkan bahwa penyimpanan bolu kukus selama 3 hari pada Angka Lempeng Total (ALT) tidak sesuai dengan standar SNI 73882009. Dari hasil pengamatan yang dilakukan hasil pada Angka Lempeng Total (ALT) tidak dianjurkan untuk dikonsumsi karena menurut SNI 7388-2009, menyatakan standar Angka Lempeng Total (ALT) pada roti yaitu batas maksimum $1 \times 10^{4} \mathrm{koloni} / \mathrm{g}$. Hasil Angka Lempeng Total tertinggi adalah pada produsen $1 \mathrm{dan}$ produsen 2 hal ini disebabkan karena pada produsen 1 dan produsen 2 ruang dan cara penyimpanan serta higienitas para produsen saat selesai pembuatan yang tidak bersih dan dapur yang digunakan untuk membuat bolu kukus kurang higenis. Dan dapat meningkatan Angka Lempeng Total pada bolu kukus tersebut. Pada produsen 3 didapatkan hasil Angka Lempeng Total terendah dibandikan pada produsen 1 dan produsen 2 dikarenakan tempat penyimpanan pada saat selesai pembuatan yang bersih dan dapur yang dipergunakan juga bersih.

Hal tersebut dibuktikan oleh Tasurini, dkk. (2015) yang melakukan 
pemeriksaan pada sampel kue basah di pasar subuh Ciamis. Hasil pemeriksaan diperoleh sampel kue basah yang dijual dipasar tersebut melebihi nilai standar SNI $7388-2009$ yaitu batas maksimum $1 \times 10^{4} \mathrm{koloni} / \mathrm{g}$. Kue dengan nilai angka lempeng total yang tertinggi adalah kue apem yaitu $8,40 \times 10^{6} \mathrm{koloni} / \mathrm{g}$, sedangkan yang terendah adalah kue carabikang yaitu $1,45 \times 10^{6}$ koloni/g. Tingginya Angka Lempeng Total (ALT) pada kue apem dipengaruhi oleh bahan utama dari kue apem tersebut. Bahan utama kue apem adalah gula pasir yang dapat dipecah oleh bakteri dan menghasilkan zat berupa monosakarida yang dapat digunakan sebagai sumber energi.

Hasil dari penelitian ini, didapatkan bahwa penyimpanan bolu kukus selama 3 hari pada Angka Kapang Khamir (AKK) tidak sesuai dengan standar SNI 7388-2009. Dari hasil pengamatan yang dilakukan hasil pada Angka Kapang Khamir (AKK) tidak dianjurkan untuk dikonsumsi karena menurut SNI 7388-2009, menyatakan standar Angka Kapang Khamir (AKK) pada roti yaitu batas maksimum $1 \times 10^{4} \mathrm{koloni} / \mathrm{g}$ produsen dengan angka kapang khamir tertinggi pada produsen 3 dan produsen 2. Tingginya Hasil Angka Kapang Khamir Pada Produsen 3 dan produsen 2 disebabkan oleh cara penyimpanan saat selesai pembuatan bolu yang disimpan di ruangan terbuka terlalu lama tanpa dikemas terlebih dahulu yang dapat menyebabkan jamur yang terdapat di ruanagn dapur tersebut mengkontaminasi bolu kukus tersebut. Dan pada produsen 1 pada saat selesai pembuatan bolu kukus, jika bolu kukus sudah mulai dingin makan produsen tersebut segera mengemas bolu kukus tersebut. Koloni yang dihitung yang yaitu koloni khamir yang berbentuk bulat, berwarna putih dan terpisah serta koloni kapang yang memiliki serabut putih seperti kapas tanpa membedakan tiap warna koloni serta tunggal. Jika terdapat koloni yang bertumpuk maka dianggap sebagai 1 koloni (Radji, 2010). Pada penelitian Pratiwi (2013) pada pengujian angka kapang khamir pada roti di pasaran didapatkan hasil pengujian yang menunjukkan bahwa angka kapang khamir dari roti yang diuji adalah $1,4 \times 10^{3} / \mathrm{g}$ dan hasil tidak memenuhi standar mutu dari Standar Nasional Indonesia SNI 7388-2009 1×104 koloni $/ \mathrm{g}$.

Aspergillus flavus (Gambar 4.1) yang berhasil diidentifikasi memiliki morfologi koloni berwarna kuning kehijauan jika dilihat secara mikroskopis memiliki konidiofor yang panjang, kepala konidial bervariasi seperti bola. Hasil pengamatan ini sesuai dengan Amalia (2013), Aspergillus flavus memiliki konidiofor yang panjang dan relatif kasar, bentuk kepala konidial bervariasi dari bentuk kolom, radial, dan bentuk bola, hifa berseptum, dan koloni kompak. Kapang ini memiliki warna permulaan kuning yang akan berubah menjadi kuning kehijauan atau coklat dengan warna inversi coklat keemasan atau tidak berwarna,sedangkan koloni yang sudah tua memiliki warna hjau tua. Berdasarkan persamaan karakteristik tersebut maka jamur kontaminan pada bolu kukus produsen 1 dan 2 diidentifikasi sebagai Aspergillus flavus.

Aspergillus fumigatus (Gambar 4.2) yang berhasil diidentifikasi memiliki morfologi koloni berwana putih, dan konidia atas berbentuk kolumer (memanjang). Hasil pengamatan ini sesuai dengan Sutanto (2008), Aspergillus fumigatus memiliki ciri-ciri mikroskopis antara lain, konidia atas berbentuk kolumer (memanjang) berwarna hijau, vesikel berbentuk pialo, dan konidiofornya berdinding halus. Koloninya berwarna hijau kebiruan-hijau tua dengan tepi putih. Berdasarkan persamaan karakteristik tersebut maka jamur kontaminan pada bolu kukus produsen 2 dan 3 diidentifikasi sebagai Aspergillus fumigatus. 
Rhizopus stolonifer (Gambar 4.3) yang berhasil diidentifikasi memiliki morfologi koloni berwarna putih keabuan, terlihat seperti kapas, dan memilki hifa yang panjang. Pada pengamatan mikroskopis terdapat kolumela yang berbentuk bulat, sporangiofor yang panjang, dan memilki sporangiospora. Hasil pengamatan ini sesuai dengan Kumala (2006), Rhizopus stolonifer memiliki karakteristik warna koloni keputihan kemudian menjadi coklat keabua-abuan, permukaan koloni terlihat seperti kapas, tidak terdapat garis-garis radial. Ciri-ciri mikoskopis Rhizopus stolonifer memilki sporangiofor yang berdinding halus dan berlawanan arah degan percabangan rhizoid, kolumela berbentuk bulat, sporangiospora berbentuk bulat dan sporangia berbentuk bulat. Berdaarkan persamaan karakteristik tersebut maka jamur kontaminan pada bolu kukus produsen 1dan 3 diidentifikasi sebagai Rhizopus stolonifer.

\section{SIMPULAN}

Berdasarkan penelitian yang telah dilakukan dapat disimpulkan bahwa:

1. Cemaran Angka Lempeng Total (ALT) pada bolu kukus yang disimpan selama 3 hari pada suhu ruangan $\left(27^{\circ} \mathrm{C}\right)$ tidak layak dikonsumsi lagi karena tingkat tercemanya bakteri pada bolu kukus tersebut sudah melebihi standar SNI 73882009 yang sudah ditetapkan yaitu: ALT dan AKK dengan batas maksimum $1 \times 10^{4} \mathrm{koloni} / \mathrm{g}$, yaitu hasil ALT sebanyak Produsen A sebanyak $897 \times 10^{4}$ $\mathrm{CFU} / \mathrm{mL}$, Produsen B sebanyak $86 \times 10^{4} \mathrm{CFU} / \mathrm{mL}$, Produsen C $167 \times 10^{4}$ $\mathrm{CFU} / \mathrm{mL}$. Hasil AKK pada Produsen A sebanyak $1,85 \times 10^{4} \mathrm{CFU} / \mathrm{mL}$, Produsen B sebanyak $8,4 \times 10^{4} \mathrm{CFU} / \mathrm{mL}$, Produsen $\mathrm{C}$ sebanyak $12,3 \times 10^{4} \mathrm{CFU} / \mathrm{mL}$.

2. Identifikasi jamur yang mengkontaminasi bolu kukus selama penyimpanan 3 hari yaitu jamur Aspergillus flavus, Aspergillus fumigatus dan Rhizopus stolonifer.

SARAN

Kepada peneliti selanjutnya, perlu menggunakan perlakuan kontrol dalam Analisa Angka Lempeng Total dan Angka Kapang Khamir dengan metode difusi. Penelitian selanjutnya dapat melakukan pengujian kembali mengenai perlakuan suhu penyimpanan bolu kukus, maupun lama penyimpanan yang dilakukan.

\section{DAFTAR PUSTAKA}

Amalia. N. 2013. Identifikasi jamur Aspergillus flavus pada Kacang Tanah (Arachis hypogae L) yang di jual dipasar Kodim. Jurnal Analis Kesehatan Klinical Sains. 1(1): 1-10.

Dewi, M. M. 2016. Uji Angka Kapang Khamir (AKK) Dan Angka Lempeng Total (ALT) Pada Jamu Gendong Temulawak Di Pasar Tamrumanegara Magelang. Skripsi dipublikasikan. Jogyakarta: Fakultas Farmasi Universitas Sanata Dharma Yogyakarta.

Handayani. 2015. Bolu kukus. (Online). (Available from: https:// eprints.ums.ac.id/ 32850/4/BAB \%201 .pdf. Diakses pada tanggal 3 Desember 2017, jam 10.00 WITA). 
Kusuma, R. 2008. Pengaruh penggunaan cengkeh (Syzygium aromaticum) dan kayu manis (Cinnamomum) sebagai pengawet alami terhadap daya simpan roti manis. Skripsi dipublikasikan. Bogor: Institut Pertanian Bogor.

Kumala, W 2006. Mikologi Dasar Kedokteran. Jakarta: Universitas Trisakti.

Pratiwi. S. T. 2008. Mikrobiologi Farmasi. Fakultas Farmasi Universitas Gajah Mada. Yogyakarta, pp: 38,135-140,206-207.

Standar Nasional Indonesia. 2009. Batas Maksimum Cemaran Mikroba dalam Pangan. Badan Standardisasi Nasional.

Susanto. 2008. Parasitologi Kedokteran. Jakarta: Fakultas Kedokteran Universitas Indonesia.

Tansaruni, D., Sri R., Irnawati., Puput S N. 2015. Pemeriksaan Angka Lempeng Total (ALT) Pada Bolu Kukus Yang Dijual Di Pasar Subuh Ciamis. Jurnal Kesehatan Masyarakat. 3(1): 1-7. 